\title{
JCNaR
}

\section{Antibacterial Activities of Rough Lemon (Citrus jambhiri Lush) Rind Essential Oil}

\author{
Helmina Br. Sembiring ${ }^{*}$, Herlince Sihotang ${ }^{1}$, Anggun CTampubolon ${ }^{1}$ \\ $1^{1 *}$ Department of Chemistry, Faculty of Mathematics and Natural Science, Universitas Sumatera Utara
}

\begin{abstract}
The isolation of rough lemon (Citrus jambhiri Lush) rind essential oil has been done by using hydrodistillation method and paper disk diffusion test for antibacterial activity test. 2.3 gram (1.51\%) of essential oil was obtained from 450 gram of dried rough lemon rind powder. Based on the analysis using GC-MS, the essential oil from rough lemon rind contains 5 chemical compounds, but only 4 of them can be interpreted. They are Limonene (71.88\%), 1,4-cyclohexadiene (13.93\%), $\beta$-Pinene (10.57\%) and $\beta$-Ocimene $(2.37 \%)$. Antibacterial activity was tested to Bacillus cereus and Escherichia coli at $40 \%$ concentration (v/v) with $12.7 \mathrm{~mm}$ and $12.9 \mathrm{~mm}$ of clear zones respectively.
\end{abstract}

Keyword:Citrus Jambhiri Lush, essential oil, antibacterial

Received November 1, 2018| Revised December 20, 2018 | Accepted January 22, 2019

\section{Introduction}

Rough lemon (Citrus jambhiri Lush) plant, also known as Sundai orange or Sundai acid, is similar to lime, but with a different kind of aroma (Baymolo, 2002). Rough lemon is commonly used by Batak Toba society as the main ingredient to make a special food called dekke naniura, in which cut carp meat is sprinkled with rough lemon essence, added some other ingredients and left for 30 minutes to serve (Purba, 2011). The addition of rough lemon enhance the aroma of the fish and still maintain the nutritional content in the fish (Tarigan et al., 2016; Manalu, 2009).

Food like carp is able to be the medium or substrate for the growth of pathogenic microorganism as causes of disease like Escherichia coli and Bacillus cereus bacteria (Siagian, 2002). Therefore, a substance that is able to kill the microorganism is needed, for instance rough lemon. To get the essence of rough lemon, the fruit is peeled and the rind is removed. The peel of fresh rough lemon contains essential oil.

\footnotetext{
*Corresponding author at:Department of Chemistry, Faculty of Mathematics and Natural Science, Universitas Sumatera Utara

E-mail address: helmina02@yahoo.com
} 
Essential oil is a complex mixture of volatile oil, or a volatile oil obtained from plants by distillation (Sastrohamidjojo, 2004; Baser, 2010; Guenther, 1987). Muhamed et al. (2013) isolated and identified the components of fresh rough lemon rind. There are 6 chemical components in the essential oil with the highest content of Limonene (84.5\%). Essential oil industry has got a high economic value as it is widely used as fragrance or flavoring in cosmetic, food, beverage, soap or medicine (Mulyani et al. 2009).

Rough lemon essential oil is useful as anti-inflammatory, antitumor, antibacterial and antifungal (Hamdan et al., 2013).Based on organoleptic test, rough lemon rind also contains essential oil, but there has not been any research done to rough lemon rind.

The aim of this study is to investigate the chemical compound in rough lemon (Citrus jambhiri Lush) rind essential oil as well as testing antibacterial activities. Essential oil was isolated using hydrodistillation method with Stahl distillation. The determination of chemical compound was done using GC-MS while antibacterial activities were tested using paper disk diffusion to Bacillus cereus and Escherichia coli bacteria.

\section{Materials and Methods}

\subsection{Research material}

Rough lemon (Citrus jambhiri Lush) rind sample used in the research was collected from Desa Pangaloan, Pahae Jae district, North Tapanuli Regency, North Sumatra. The chemical used were anhydrous $\mathrm{Na}_{2} \mathrm{SO}_{4}$ and DMSO from Fison. Bacteria used were Bacillus cereus and Escherichia coli. Agar nutrient, Broth nutrient and Mueler Hinton agar (MHA) from Oxoid were used as the medium.

\subsection{Research equipment}

This research used GC-MS (QP2010S SHIMADZU) equipment, a set of hydrodistillation equipment and an autoclave (Yamato SN 20).

\subsection{Rough Lemon Rind Essential Oil Isolation}

Essential oil was isolated based on the procedure by Bausbia et al. 2009. As much as 150 gram of dried rough lemon peel powder was inserted into $1000 \mathrm{~mL}$ hydrodistillation flask. $200 \mathrm{ml}$ of distilled water was added and put to boil for 5 hours in an oil bath until essential oil evaporated. The distillate obtained was a mixture of essential oil with water. Next, it is separated with a separating funnel. Essential oil collected was dried by adding $\mathrm{Na}_{2} \mathrm{SO}_{4}$ anhydrous. Oil was kept in a fridge at $4^{\circ} \mathrm{C}$ before its use. The chemical component in the oil was anlysed with GC-MS and antibacterial activities test was done using paper disk diffusion method.

\subsection{Antibacterial Activities Test of Rough Lemon Rind Essential Oil}


Antibacterial activities was conducted based on test procedure by Mithraja et al. (2012). MHA, $\mathrm{NB}$ and bacterial inoculum media in NB were prepared following the procedure byTendencia(2004) and Bauer et al. (1966). Then the concentration of essential oil from rough lemon rind was varied from 25,30, 35 to $40 \%$ (v/v) with DMSO solvent. $0.1 \mathrm{ml}$ Bacillus cereus inoculum was put onto petri dish and $15 \mathrm{ml}$ of MHA was added at $45^{\circ} \mathrm{C}-50^{\circ} \mathrm{C}$, homogenized and left until the media solidified. Paper disk with essential oil was put and incubated at $35^{\circ} \mathrm{C}$ for 24 hours in an incubator (Mithraja et al., 2012). Clear zone around paper disk was measured using a caliper.

\section{Results And Discussion}

\subsection{The Isolation of Rough Lemon Rind Essential Oil}

Essential oil from rough lemon peel was obtained through hydrodistillation method with hydrodistillation equipment. Distillation process was done for three times, each procedure used 150 gram of dried rough lemon powder which summed up to 450 gram of powder used. 2.3 gram $(1.51 \%)$ of colorless essential oil with a distinct smell was produced.

In order to know the chemical components and the content of each in the essential oil, GC-MS analysis was conducted. Based on GC-MS chromatogram for rough lemon rind essential oil (Figure 1.) shows that there are 5 peaks which mean that the essential oil has got 5 chemical compounds where 4 of them are interpretable based on Wiley and Nist Library shown in Table 1.

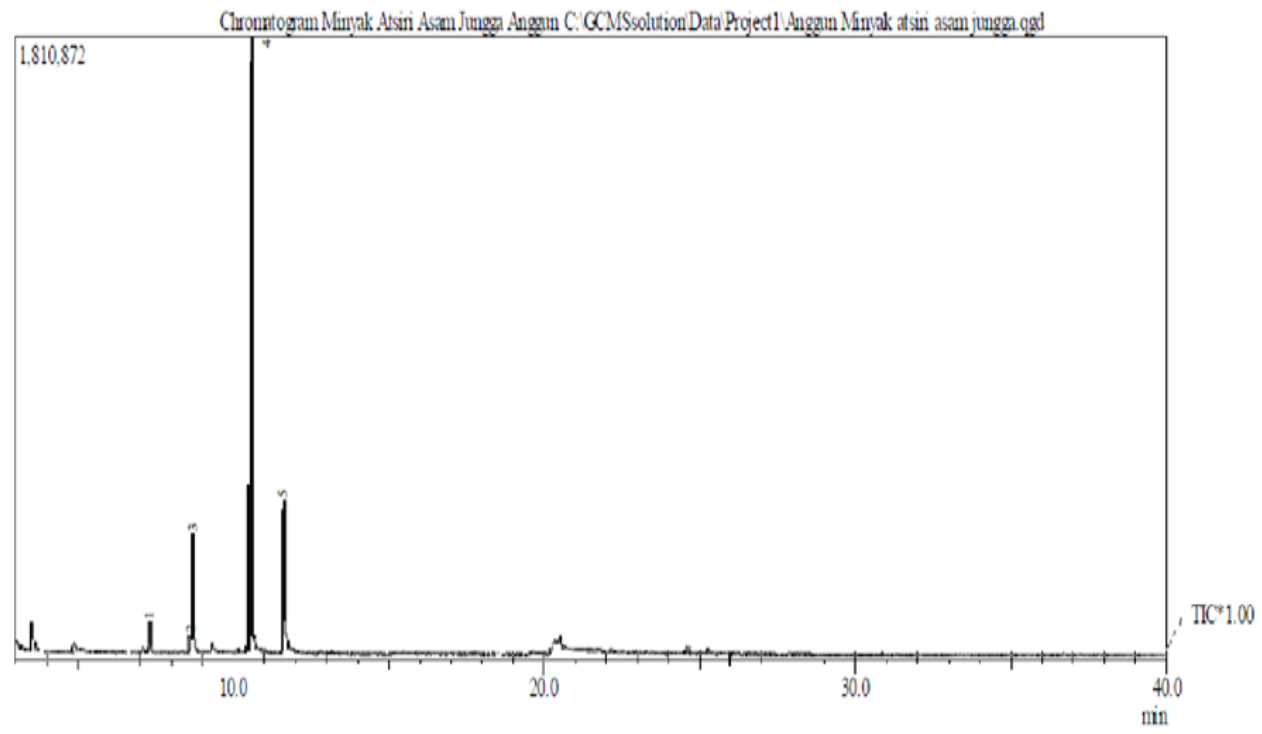

Figure 1.GC-MS chromatogram for rough lemon rind essential oil 
Table 1.Chemical components in rough lemon rind essential oil

\begin{tabular}{llllll}
\hline $\begin{array}{l}\text { Peak } \\
\text { No. }\end{array}$ & $\begin{array}{l}\text { Retention } \\
\text { Time } \\
(\text { minute(s) })\end{array}$ & $\begin{array}{l}\text { Molecule } \\
\text { Mass }\end{array}$ & $\begin{array}{l}\text { Molecule } \\
\text { Formulae }\end{array}$ & Chemical Compound & Area (\%) \\
\hline 1 & 10.577 & 136 & $\mathrm{C}_{10} \mathrm{H}_{16}$ & Limonen & 71.88 \\
\hline 2 & 11.590 & 136 & $\mathrm{C}_{10} \mathrm{H}_{16}$ & 1,4 -Sikloheksadiena & 13.93 \\
\hline 3 & 8.701 & 136 & $\mathrm{C}_{10} \mathrm{H}_{16}$ & $\beta$-Pinen & 10.57 \\
\hline 4 & 7.291 & 136 & $\mathrm{C}_{10} \mathrm{H}_{16}$ & $\beta$-Ocimen & 2.37 \\
\hline
\end{tabular}

The most dominant compound in the rough lemon peel essential oil, with a content of $71.88 \%$, is limonene, $\mathrm{C}_{10} \mathrm{H}_{16}$, with 10.577 minutes of retention time. The spectra shows the peak of ion molecule at m/e 135 and fragmentation peaks at m/e 121, 107, 93, 79, and 68. By comparing spectra obtained with the reference from the library, the compound with the closest mass spectra is Limonene, as shown in Figure 2 and the fragmentation pattern hypothetically is shown in

Figure 3.

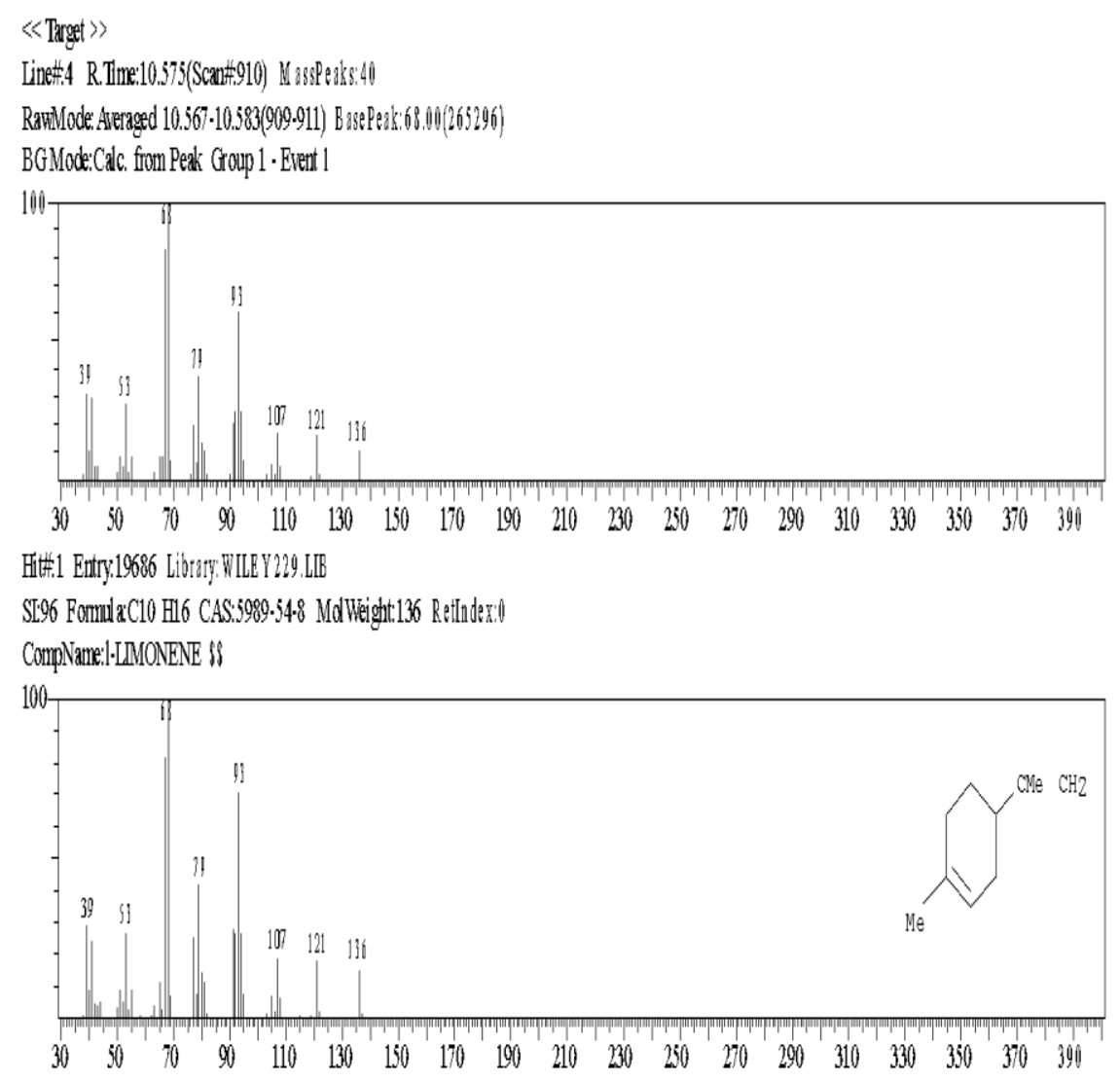

Figure 2(a) Mass Spectrum of GC-MS analysis for limonene compound;

(b) Standard Wiley library 


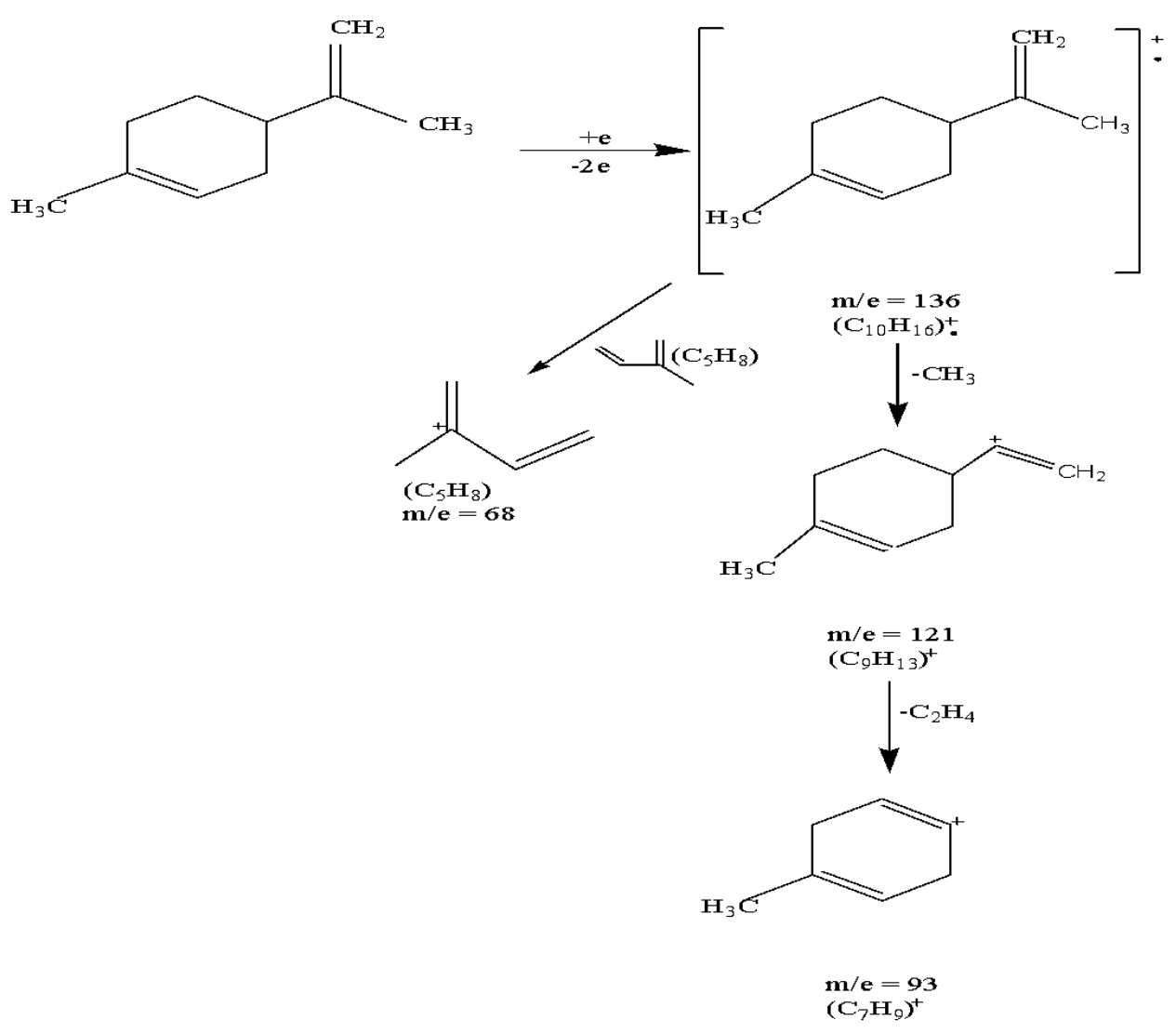

Figure 3 Fragmentation pattern for Limonene compound

\subsection{Antibacterial Activities of Rough Lemon Rind Essential Oil}

Antibacterial activities were determined using paper disk diffusion method. The ability of rough lemon peel essential oil to inhibit bacterial growth was observed from the clear zone appeared around the paper diskagainst Escherichia coli and Bacillus cereus, as shown in Table 3.

Table 3. Clear zone diameters against bacterial growth with rough lemon rind essential oil

\begin{tabular}{ccc}
\hline $\begin{array}{c}\text { Essential Oil Concentration } \\
(\%)\end{array}$ & \multicolumn{2}{c}{$\begin{array}{c}\text { Clear zones diameter against bacteria with essential oil } \\
(\mathrm{mm})\end{array}$} \\
\cline { 2 - 3 } & Escherichia coli & Bacillus cereus \\
\hline $25 \%$ & 9.2 & 9.6 \\
$30 \%$ & 10.4 & 10.5 \\
$35 \%$ & 10.7 & 12.5 \\
$40 \%$ & 12.9 & 12.7 \\
\hline
\end{tabular}

Table 3 shows that the higher essential coil concentration is, the bigger the clear zones because there is more active ingredients diffused through the paper disk towards bacteria. Based on Clinical and Laboratory Standards Institute (2012), a substance has a weak antibacterial 
activities with clear zone diameter of $\leq 12 \mathrm{~mm}$, moderate category when clear zone diameter is between $13-17 \mathrm{~mm}$ and strong category when the diameter is $\geq 18 \mathrm{~mm}$. Rough lemon rind essential oil is in moderate category towards Bacillus cereus and Escherichia coli at concentration of $40 \%$ with each clear zone is at $12.7 \mathrm{~mm}$ and $12.9 \mathrm{~mm}$ respectively.

The result of this research shows that clear zone bacteria formed from rough lemon peel essential oil is bigger towards gram-positive bacteria (Bacillus cereus) than negative-gram bacteria (Escherichia coli). This is because gram-poistive bacteria is more sensitive to active ingredients than negative-gram bacteria. The cell wall structure of gram-positive bacteria is simpler with a singular layer and simpler lipid content $(1-4 \%)$ which ease the penetration of active ingredients to the cell. On the other hand, negative-gram bacteria is more complex with lipoprotein of outer layer and polysaccharide as mid-layer which act as a barrier for active ingredients to enter. Furthermore, the inner layer is peptidoglycan with high lipid content (11 22\%) (Mulyani, 2009; Chan et al., 2010).

\section{Conclusion}

3.6 gram $(0.8 \%)$ of essential oil was produced from 450 gram of dried rough lemon rind powder. GC-MS analysis showed that rough lemon rind essential oil contains 5 chemical components with 4 of them were interpretable as Limonene (71.88\%), 1,4-cyclohexadiene (13.93\%), $\beta$-Pinene (10.57\%) and $\beta$-Ocimene (2.37\%). Antibacterial activity was tested to Bacillus cereus and Escherichia coli at $40 \%$ concentration $(\mathrm{v} / \mathrm{v})$ with clear zones of $12.7 \mathrm{~mm}$ and $12.9 \mathrm{~mm}$ respectively.

\section{Acknowlegements}

This work was supported by the head laboratory of organic chemistry for biological matters, head of microbiology pharmacy laboratory of Universitas Sumatera Utara, head of Integrated Research and Testing Laboratory (LPPT) UGM Yogyakarta and to the people in Desa Pangaloan, Pahae Jae District, North Tapanuli Regency - North Sumatra.

\section{Reference}

Baser, K. H. C., 2010.Handbook of Essential Oils science, technology and Applications.CRC Press. London New York P. 39-40.

Bousbia, N., Vian, M.A., Ferhat, M.A., Petitcolas, E., Meklati, B.Y. and Chemat, F., 2009.

Baymolo, G., 2002. The Effects of Potting Sizes on the Growth of Rough Lemon (Citrus jambhiri Lush) Rootstocks. [Disertasi].Departement of Crop Sciences.School of Agricultural Sciences.University of Zambia.

Chan, Kong, M., Guang, X., Xing, K. and Park, H.J., 2010.Antimicrobial Properties of Chitosan and Mode of Action: A State of the Art Review. International Journal of Food Microbiology. (44), 51- 63.

Guenther, E., 1987. Minyak Atsiri. Jilid 1.UI-Press.

Hamdan, D.I., Abdulla, H., Mohamed, M.E.and El-Shazly, A.M., 2013. Chemical composition and biological activity of essential oils of Cleopatra mandarin (Citrus reshni) cultivated in Egypt. Journal of Pharmacognosy and Phytotherapy. 5 (5), 83 - 90. 
Manalu, M.BF., 2009. Memperkenalkan Naniura Makanan Khas Bataksebagai Hidangan Appetizer.Majalah Ilmiah Panorama Nusantara Edisi VII, 52-61.

Mithraja, M.J., Irudayaraj, V., Kiruba, S. and Jeeva, S., 2012.Antibacterial Efficacy of Drynaria quercifolia (L.) J. Smith (Polypodiaceae) Against Clinically Isolated Urinari Tract Pathogens. Asian Pacific Journal of Tropical Biomedicine, S131 - S135.

Muhamed, A. M.E., Ibrahim, A.M., Omran, A.A., Mohamed, M.E., and Elsheikh, S.E.M., 2013. Minerals content, essential oils composition and physicochemical properties of Citrus jambhiri Lush. (Rough Lemon) from the Sudan.International Letters of Chemistry, Physics and Astronomy 9 (1), 25-30.

Mulyani, S., 2009. Analisis GC-MS dan daya anti bakteri minyak atsiri Citrus amblycarpa (Hassk) Ochse .Majalah Farmasi Indonesia.

Purba, A., 2011. Pengaruh Proses Pembuatan Dekke Naniura Terhadap Pertumbuhan Bakteri.[Skripsi]. Medan. Fakultas Farmasi USU.

Sastrohamidjojo, H., 2004. Kimia Minyak Atsiri. Cetakan Pertama. UGM-Press. Yogyakarta.

Siagian, A., 2002. Mikroba Patogen pada Makanan dan Sumber Pencemarannya, Fakultas Kesehatan Masyarakat. Universitas Sumatera Utara. USU digital library.

Tarigan, O.J., Lestari, S. dan Widiastuti, I., 2016. Pengaruh Jenis Asam dan Lama Marinasi Terhadap Karakteristik Sensoris, Mikrobiologis, dan Kimia Naniura Ikan Nila (Oreochromis Niloticus). Jurnal Teknologi Hasil Perikanan. 5 (2), 112 - 122.

Tendencia, E. A., 2004. Chapter 2.Disk diffusion method. In Laboratorymanual of standardized methods for antimicrobial sensitivity tests for bacteria isolated from aquatic animals and environment. Tigbauan, Iloilo, Philippines: Aquaculture Department, Southeast Asian Fisheries Development Center, 13 - 29. 